\title{
Degenerated Leukocyte Count
}

National Cancer Institute

\section{Source}

National Cancer Institute. Degenerated Leukocyte Count. NCI Thesaurus. Code C111190.

The determination of the amount of degenerated leukocytes (leukocytes that show deterioration in form or function) present in a sample. 